\title{
Assessment of the local varieties of the fig (Ficus carica $L$ ) tree in Moukrisset area of Morocco
} El Oualkadi A*, Hajjaj B*

*INRA- Regional Agricultural Research Center of Tangier, Morocco Corresponding author. E-mail: ai.oualkadi@gmail.com

\begin{abstract}
In Morocco, the cultivation of the fig tree has an ancestral character, the villagers of some production areas claim that its culture is very old and that the dried fruit traded with cereals, coming from Gharb. Its cultivation, which once covered a number of flat lands, is currently limited to hills, sloping land and housing. The aims of our study were to identify and characterize the richness of fig tree. For that the prospection of fig tree plants was carried out in Moukrisset region of morocco during the period from 2015 to 2016. A total of 300 accessions were sampled, studied and identified by used the biometric analyses. As a result of the study a total of 30 different fig varieties were identified. Several synonymies and homonymies were detected. Comparison of the ecotype shows the high significatif difference.
\end{abstract}

Keywords-fig tree, genetic resources, biometric analysis, Moukrisset region, Morocco.

\section{INTRODUCTION}

Fig is one of the oldest known fruit trees in the world. It's considered as sacred fruit in all sacred books and it played an important role in the mythology of many societies. Botanically identified as Ficus carica L., the common fig belongs to the family of Moraceae. The somatic chromosome number is $2 \mathrm{n}=2 \mathrm{x}=26$ [1], [2]. Fresh and dried figs formed a large part of human food [3]. Figs may be processed or cooked in various ways. Commercial canning and drying of figs are actually industries of great importance.

In Morocco, the fig is considered a minor fruit species although it socioeconomic and historical importance. The regions in which the fig tree assumes economic importance are Taounate (22230 ha), Chefchaouen (7050 ha), Al Hoceima (5000 ha), Ouazzane (3150 ha), Tetouan (2000 ha) [4]. In Morocco, the production of fresh figs in 2018 growing season for fresh consumption was approximately 57000 tons with a total area of 46000 hectares (ha) of fig plantations [4]. Particularly, in rural area, fig production assumes economic importance mainly in Moukrisset area. This area is rich in figs with much diversified varieties, but with a lack of knowledge of caprification techniques. But a lot of problem hinders the maintenance of the fig tree growing in this region. In the area of Moukrisset where the shale dominates, land erosion is widespread. The steep slopes are overgrown with water throughout the winter season, resulting in mass movements of entire fields uprooting fruit trees. In addition, the introduction of the plum tree in the Zoumi and Moukrisset areas has driven the fig tree out of the main irrigated and fresh fields. This rapid extension of the plum tree shows that they have met climatic and edaphic conditions favorable to their development.

Evaluation of genetic variations within cultivated crop species is central to plant breeding strategies and genetic resource conservation [5]; [6]. Morphological and agronomic characters are useful in surveys of plant species diversity but these characters are highly influenced by environmental conditions. To overcome this, a large array of molecular markers is increasingly used to assess genetic polymorphism. Unfortunately, there has been little research dealing with the genetic diversity in fig germplasm [7], [8]; [9], [10]; [11]; [12]. In morocco, surveys done in different regions of Morocco contributed to identify and describe numerous cultivars [13]; [14]; [15]; [16].

In morocco, the fig tree plays a significant economic role in the diet of the population of the North region. However, the marketing of the product is little developed in our time and this after having had a much greater importance in the past. In order to analyze the constraints on the production and marketing of figs, important factors for the development of this sector, particularly the knowledge and characterization of local varieties, must be taken into account. In this context, a study identifying these different aspects of the subject was carried out in the Moukrisset region in the North West of Morocco.

\section{MATERIAL AND METHODS}

Prospection and sampling have been carried out at different localities in Moukrisset region in Northwestern of 
morocco (fig. 1). In total 300 accessions were gathered. In many cases, either isolated plants or plants located at old fig plantations areas were sampled (Table 1).

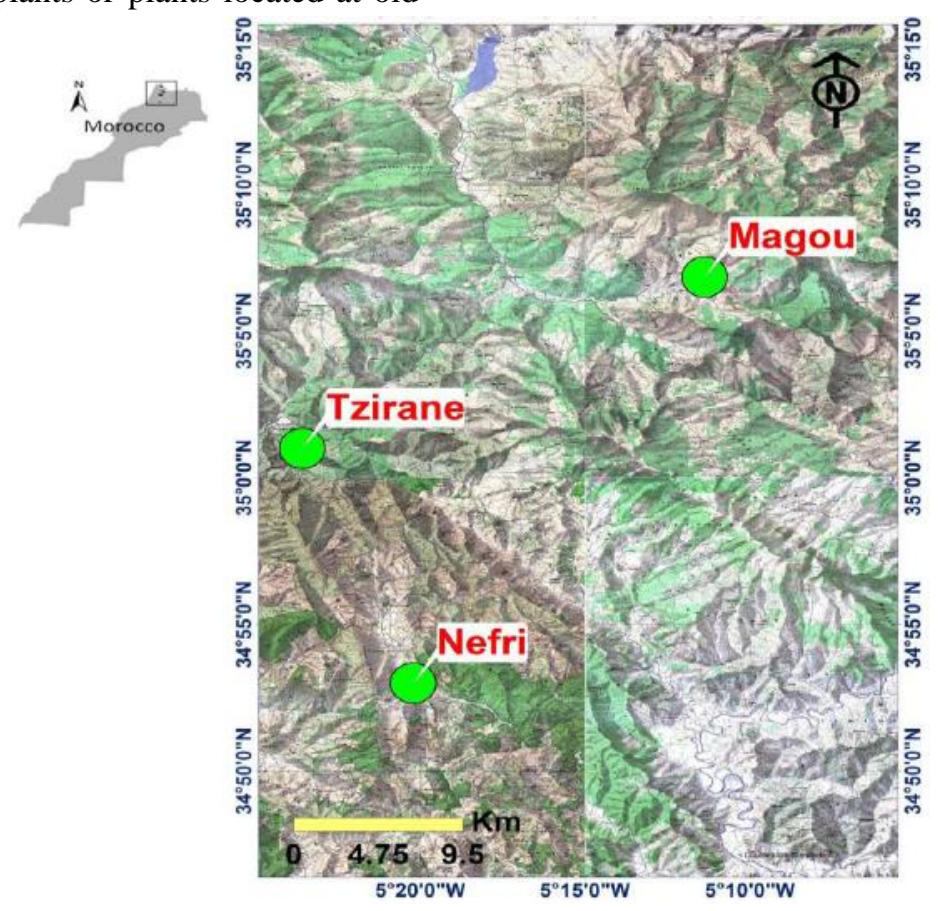

Fig. 1. Collection sites.

Table 1: Location of prospecting sites

\begin{tabular}{|c|c|c|c|c|c|}
\hline Number of ecotype & Douar & Caîdat & Locatlity & Altitude & Geographic coordinate \\
\hline \multirow{2}{*}{100} & \multirow{2}{*}{ Magou } & \multirow{2}{*}{ Bab taza } & \multirow{2}{*}{ Bab taza } & \multirow{2}{*}{$789 \mathrm{~m}$} & $35^{\circ} \mathrm{N}-06,847^{\prime}$ \\
\hline & & & & & $0,05^{\circ} \mathrm{W}-11,377^{\prime}$ \\
\hline \multirow{2}{*}{100} & \multirow{2}{*}{ Tzirane } & \multirow{2}{*}{ Moukrisset } & \multirow{2}{*}{ Moukrisset } & \multirow{2}{*}{$386 \mathrm{~m}$} & $35^{\circ} \mathrm{N}-01,004^{\prime}$ \\
\hline & & & & & $0,5^{\circ} \mathrm{W}-23,574^{\prime}$ \\
\hline \multirow{2}{*}{100} & \multirow{2}{*}{ Nefri } & \multirow{2}{*}{ Zoumi } & \multirow{2}{*}{ Zoumi } & \multirow{2}{*}{$572 \mathrm{~m}$} & $34^{\circ} \mathrm{N}-52,9971^{\prime}$ \\
\hline & & & & & $0,5^{\circ} \mathrm{W}-20,213^{\prime}$ \\
\hline
\end{tabular}

\section{Plant material}

Fig fruits from thirty cultivars (Lkourti, Silfafn Lqouti, Rhouddane, Lharchi lkhal, Aounq hmam, Zenfoukh, Maalmnous, Lqouti, Herich, Lmdar, Lgouhri, Hmir, Tabli, Lkhoumsi, kouzi, Lmdar lkhal, Hafr lbghal, Lmdar lebied, Kharar, Smouni, Sabaa wrkoud, Lkouhli, Lferzaoui, Hafr Lbral, Snani, Ournaksi, Achir, Lemti) were harvested from the three respective areas during cropping seasons 2015 and 2016. Cultivars were selected for their large distribution and their commercial value in the three regions. Samples of 300 homogenous fruits were chosen for each ecotype. Fruits were selected ripe and free from diseases.

\section{Pomological characters \\ Biometric Approach}

To examine the characteristics of the fruit for each ecotype, it was considered useful to approach a biometric study of the fruit based on the evaluation of the weight, caliber, dimensions and ostiole of the fruit. For each ecotype, a sample of twenty four fruits was randomly collected from different branches of the tree. Fruit weight was measured using a laboratory precision balance. Dimensions of the fruits such length, width, height and ostiole width were measured using a caliper (Fig. 2). The descriptors used were adapted list drawn up by European program GEN LMBO 029 [14].

\section{General appearance of the fruit:}

The general appearance of the fruit corresponds to its external form. In this aspect, we were interested in the shape and size of the fruit. 


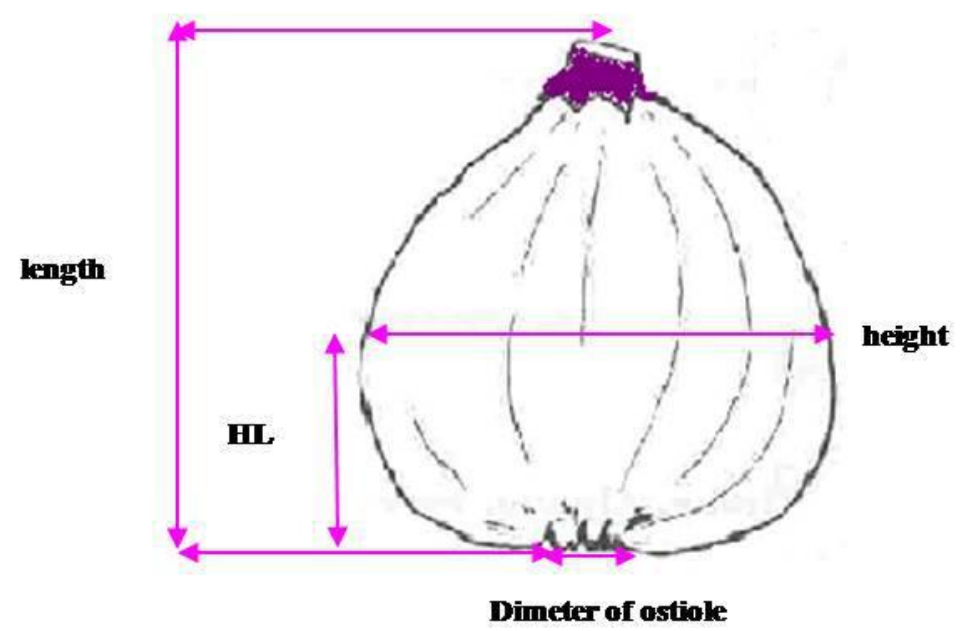

Fig 2: Representative diagram of measurements made on fig fruit

\section{Fruit Shape}

The fruits are of variable shape within the same tree and during the same season [15]. To avoid this hazard, we often rely on the presence or absence of neck. Other authors rely on three dimensions of the fruit to differentiate the varieties: the length $\mathrm{C}$, the diameter $\mathrm{D}$, and the distance A separating the base from the center of the circle of diameter D. The study of the shape of the fruit is important because it is related to the treatment that is applied to it. This is how the flattened shape with a short neck is ideal for canning. Other forms require certain precautions during transport; and others may facilitate the marketing of fresh fruits.

\section{Statistical analysis}

Comparison between the ecotype was made by statistical analysis of collected data. Statistical analyzes are performed with SPSS software version 21 .

\section{RESULTS AND DISCUSSION}

300 accessions were identified in Moukrisset region. Many of the sampled accessions were collected either as unidentified or with local names. As result of the biometric approach the prospected plant material was characterized. The average weight of the varieties studied varied from $13.7 \mathrm{~g}$ to $71.5 \mathrm{~g}$ (Table 2). The Zenfoukh variety shows the highest weight while the Kouzi variety shows the lowest weight. The analysis of variance showed fifteen homogeneous groups from the weight fruit (Table 2).

The average length of the fruit varied between $5.26 \mathrm{~cm}$ and $3.01 \mathrm{~cm}$ (Table 2), the variety Saidi showed the height value of the length of the fruit whereas the variety Kouzi showed the lowest value of the length of the fruit. We distinguished 16 groups significantly different from the Length of fruit (Table 2). The variety Smouni, Lgouhri, Maalmnous, Lemti, Kharar, Herich are not significantly different. The variety Kouzi, Silfaf, Hmir, Snani, Hafr lbral Rhouddane, Aounq hmam, Sabaawrkoud, Lkourit, Saidi each one formed one group significantly different to the other group (Table 2).

The width of the fruit varied between $2.98 \mathrm{~cm}$ and $5.73 \mathrm{~cm}$ (Table 2), the Gouzi variety shows the weaker value of width fruit while the variety Zenfoukh shows the greatest value of the width of the fruit (Fgi.5). The analysis of variance shows eighteen groups significantly different from the width of fruit. The varieties Lkouhli, Larchi, Lkhal, Lkhoumsi, Snani are significantly not different for the parameter Width of fruit (Table 2).

The value of HL varied between $1.53 \mathrm{~cm}$ and $5.15 \mathrm{~cm}$ (Table 2), the variety Lkourti shows the greatest value while the variety Gouzi shows the lowest value of HL. The analysis of variance shows twenty one groups significantly different from the parameter HL (Table 2).

The diameter of the ostiole varied between $0.310 \mathrm{~cm}$ and $1.40 \mathrm{~cm}$ (Table 2) the variety Lkouhli shows the smallest value of the diameter of the ostiole whereas the variety Lgouti shows the greatest value of the diameter of the ostiole. The analysis of variance shows that the variety Lkourti, Lharchi lkhal, Zenfoukh, Maalmnous, Lqouti, Herich, Lgouhri, Aounq hmam, Lkhoumsi, Lmdar lkhal, Smouni, Sabaawrkoud, Lferzaoui, Hadr lbral, Ournaksi are not significantly different (Table 2).

The length/ Width ratio of the fruit varies between 0.72 and 1.25 (Table 2), the greatest value of the length / width ratio of the fruit was observed in the Saidi variety, while the lowest value was observed in the variety Zenfoukh. The analysis of variance shows five groups significantly different. The variety Rhouddane and Saidi are significantly different from the ratio Length/width (Table 2). 
The length / HL of the fruit varied between 1.37 and 2.75 (Table 2), it is found that the variety Lferzaoui showed the lowest value of the ratio length / HL while the variety Saidi showed the most great value. Table 2 shows fifteen groups significantly different (Table 2).

In these results, we find that the variety Kouzi (Fig 3) showed the greatest value of the weight of the fruit, the
Length and the width of the fruit. However the Saidi variety (Fig 4) showed the greatest value of the Length, Length/Width and Length/HL, when the variety Lemti (Fig 5) show the high value of Diameter of ostiole.

Table 2: Biometric characteristics of fig cultivars harvested from the region

\begin{tabular}{|c|c|c|c|c|c|c|c|}
\hline & Weight (g) & Length $(\mathrm{cm})$ & Width (cm) & $\mathrm{HI}(\mathrm{cm})$ & $\begin{array}{l}\text { Diameter of } \\
\text { ostiole }(\mathrm{cm})\end{array}$ & Length/Width & Length / HL \\
\hline LKourti & $59,5 \mathrm{i}$ & $4,87 \mathrm{ij}$ & $5,15 \mathrm{~m}$ & $5,15 \mathrm{~m}$ & $0,83 \mathrm{abcd}$ & $0,93 \mathrm{abcd}$ & 1,74 abcdefg \\
\hline Silfaf & $20,5 \mathrm{abc}$ & $3,2 \mathrm{ab}$ & $3,50 \mathrm{bcd}$ & 2,04 bcdef & $0,414 \mathrm{ab}$ & $0,92 \mathrm{abcd}$ & 1,57 abcdef \\
\hline L'Qouti & $35,1 \mathrm{def}$ & 3,82 bcdefg & 4,31 hijk & 2,26 efghi & $1,40 \mathrm{e}$ & $0,893 \mathrm{abcd}$ & 1,68 abcdefg \\
\hline $\begin{array}{l}\text { Rhouddane } \\
\text { Lharchi }\end{array}$ & $26,9 \mathrm{bcd}$ & 4,40 fghi & 3,57 bcde & 2,31 fghij & $0,342 \mathrm{ab}$ & $1,24 \mathrm{~cd}$ & 1,92 defgh \\
\hline lkhal & $25,7 \mathrm{abcd}$ & 3,76 bcdef & 3,86 cdefgh & $1,91 \mathrm{bcd}$ & 0,63 abcd & 0,97 abcd & 1,63 abcdefg \\
\hline $\begin{array}{l}\text { Aounq } \\
\text { hmam }\end{array}$ & 28,8 bcde & 4,41 ghi & 3,71 bcdef & 2,03 bcdef & $0,50 \mathrm{abc}$ & $1,19 \mathrm{bcd}$ & $2,19 \mathrm{~h}$ \\
\hline Zenfoukh & $71,5 \mathrm{j}$ & 4,15 defg & $5,73 \mathrm{n}$ & 3,011 & $0,70 \mathrm{abcd}$ & $0,72 \mathrm{a}$ & $1,37 \mathrm{a}$ \\
\hline Maalmnous & 37,02 defg & 3,67 bcde & $4,50 \mathrm{ijkl}$ & 2,19 bcdefghi & $0,570 \mathrm{abcd}$ & $1,15 \mathrm{bcd}$ & 1,68 abcdefg \\
\hline Lqouti & $25,3 \mathrm{abcd}$ & 3,85 bcdefg & 3,72 bcdef & 1,97 bcdef & 0,57 abcd & $1,02 \mathrm{abcd}$ & 1,91 defgh \\
\hline Herich & 35,7 defg & 3,7 bcde & $4,50 \mathrm{ijkl}$ & 2,24 defghi & $0,68 \mathrm{abcd}$ & $0,84 \mathrm{a}$ & 1,66 abcdefg \\
\hline Lmdar & $26,7 \mathrm{bcd}$ & $3,4 a b c$ & 3,98 defghi & 2,13 bcdefgh & $0,425 \mathrm{ab}$ & $0,86 \mathrm{a}$ & 1,62 abcdefg \\
\hline L'gouhri & 31,08 bcdef & 3,63 bcde & 4,03 efghi & 2,01 bcdef & $0,64 \mathrm{abcd}$ &, $895 \mathrm{abcd}$ & 1,71 abcdefg \\
\hline Hmir & 34,2 def & $3,5 \mathrm{abcd}$ & 4,43 ijkl & 2,25 defghi & 0,98 cde & $0,82 \mathrm{a}$ & 1,57 abcdef \\
\hline Tabli & $42,4 \mathrm{fg}$ & 3,91 cefg & $4,58 \mathrm{jkl}$ & $2,51 \mathrm{ijk}$ & $0,52 \mathrm{abcd}$ & $0,848 \mathrm{a}$ & $1,55 \mathrm{abcd}$ \\
\hline Lkhoumsi & $26,6 \mathrm{bcd}$ & 3,9 cefg & 3,90 cdefgh & 2,06 bcdefg & $0,51 \mathrm{abcd}$ & $1,01 \mathrm{abcd}$ & 1,80 bcdefgh \\
\hline Kouzi & $13,7 \mathrm{a}$ & $3,01 \mathrm{a}$ & $2,98 \mathrm{a}$ & $1,53 \mathrm{a}$ & $0,340 \mathrm{ab}$ & $1,01 \mathrm{abcd}$ & $1,97 \mathrm{fgh}$ \\
\hline Lmdar lkhal & 40,1 efg & 4,05 cefg & $4,50 \mathrm{jkl}$ & $2,60 \mathrm{jk}$ & $0,70 \mathrm{abcd}$ & ,90 abcd & 1,56 abcde \\
\hline Hafr lbghal & 32,4 cdef & 4,13 defg & 4,06 efghi & 2,23 cdefghi & 0,86 bcd & $1,01 \mathrm{abcd}$ & 1,86 bcdefgh \\
\hline Lmdar lbeid & $47,7 \mathrm{~h}$ & 3,9 cefg & 4,70 klm & $2,70 \mathrm{k}$ & $1,05 \mathrm{de}$ & $0,84 \mathrm{a}$ & $1,46 a b$ \\
\hline Kharar & $19,3 \mathrm{ab}$ & 3,7 bcde & $3,40 \mathrm{abc}$ & $1,89 \mathrm{bc}$ & $0,350 \mathrm{ab}$ & 1,09 abcd & 1,96 defgh \\
\hline $\begin{array}{l}\text { Smouni } \\
\text { Sabaa }\end{array}$ & $42,9 \mathrm{fg}$ & 3,61 bcde & $4,84 \mathrm{lmn}$ & 2,42 hijk & $0,68 \mathrm{abcd}$ & $0,74 \mathrm{a}$ & $1,492 \mathrm{abc}$ \\
\hline wrkoud & $60,3 \mathrm{i}$ & 4,76 hij & $4,75 \mathrm{klm}$ & 2,38 ghijk & $0,70 \mathrm{abcd}$ & $1,01 \mathrm{abcd}$ & 1,62 abcdefg \\
\hline Lkouhli & 25,6 abcd & 3,78 bcdefg & 3,84 cdefgh & 2,23 cdefghi & $0,310 \mathrm{a}$ & ,97 abcd & 1,67 abcdefg \\
\hline LFrzaoui & $47,1 \mathrm{~h}$ & $3,4 a b c$ & 4,78 klm & 2,52 ijk & $0,58 \mathrm{abcd}$ & $0,722 \mathrm{a}$ & $1,37 \mathrm{a}$ \\
\hline Hafr lbral & $60,07 \mathrm{i}$ & 4,23 efgh & $5,11 \mathrm{~m}$ & 2,52 ijk & $0,61 \mathrm{abcd}$ & $0,82 \mathrm{a}$ & 1,67 abcdefg \\
\hline Snani & 28,3 bcde & 4,2 defgh & 3,90 cdefgh & 2,08 bcdefg & $0,460 \mathrm{abc}$ & $1,08 \mathrm{abcd}$ & $2,02 \mathrm{gh}$ \\
\hline Saidi & 34,4 def & $5,26 \mathrm{j}$ & 4,26 ghijk & 1,93 bcde & $0,490 \mathrm{abc}$ & $1,25 \mathrm{~d}$ & $2,75 \mathrm{i}$ \\
\hline Ournaksi & $25,9 \mathrm{abcd}$ & 3,84 bcdefg & 3,77 bcdefg & 1,95 bcde & 0,67 abcd & $1,02 \mathrm{abcd}$ & 1,96 defgh \\
\hline Achir & $18,7 \mathrm{ab}$ & 3,78 bcdefg & $3,26 \mathrm{ab}$ & $1,86 \mathrm{~b}$ & $0,490 \mathrm{abc}$ & $1,15 \mathrm{bcd}$ & 1,87 cdefgh \\
\hline Lmeti & $19,7 \mathrm{ab}$ & 3,6 bcde & $3,31 \mathrm{ab}$ & $1,88 \mathrm{~b}$ & $0,370 \mathrm{ab}$ & $1,09 \mathrm{abcd}$ & 1,97 efgh \\
\hline$P \alpha=0.05$ & 0 & 0 & 0 & 0 & 0 & 0 & 0 \\
\hline
\end{tabular}

Significant differences within the same column and means followed by the same letter do not differ at P $\alpha \leq 0.05$ according to 


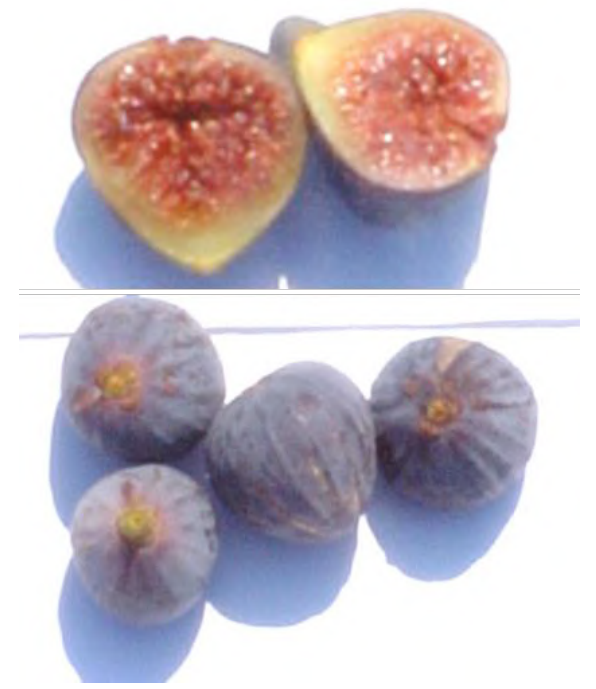

Fig 3. Variety Kouzi from Moukrisset Region

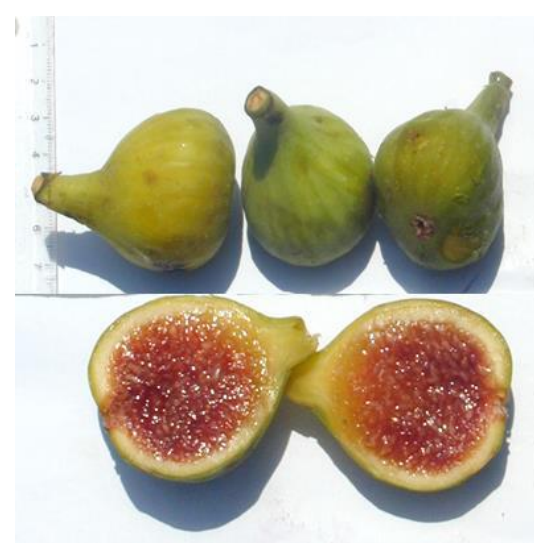

Fig 4: Variety Saidi from Mokrisset region

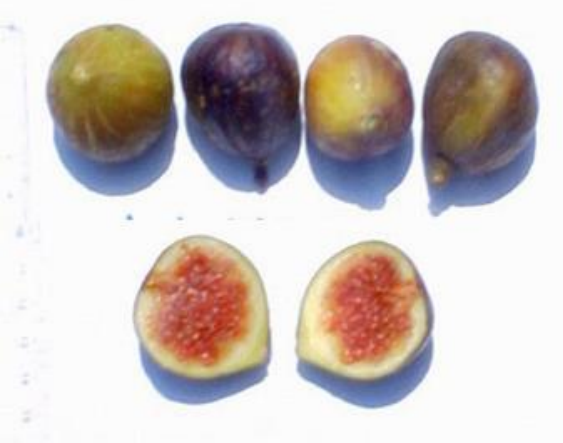

Fig 5: variety Lemti from Mokrisset region

\section{CONCLUSIONS}

The results of this study give us knowledge of diversity and pomological characteristics of the fig tree in Moukrisset region of morocco. The fig tree in this zone does not show good performances. The size of the trees is very small, with less dense foliage. The yield is quite low. The skin of the fruit is thick and resistant. Fresh consumption of most varieties seems the most interesting. The fruit resists transport thanks to its firmness and the resistance of its skin. 30 local varieties were listed in this study and showed high biometric characteristic. The richness of fig tree in this region was very important and we suggest the program for the conservation of these resources genetic.

\section{ACKNOWLEDGMENT}

The authors are grateful to all farmers in Moukrisset region for providing necessary facilities for conducting this research work.

\section{REFERENCES}

[1] Storey, W.B., (1975) Figs. In Janick J. and J. Moore (eds.), Advances in fruit breeding. Purdue Univ. Press. Indiana, $1975: 568$ - 589.

[2] Jona B. and Gribaudo, I (1991) Ficus spp. In: Biotechnology in Agriculture and Forestry, Vol. 16, trees III (ed. by Y.P.S. Bajaj): 76 - 93.

[3] Ahmed, W. and M. Abdul-Mali (1994) Phytochemical studies on the constituents of Ficus carica (fig). HamdradMedicus, 1994, 37: 2, 30 - 53

[4] DPA Hoceima (2018) Direction provinciale de l'agriculture d'Al Hoceima 2018.

[5] Dean, R.E., J.A. Dahlberg, M.S. Hopkins, Cabrita, L.F., U. Aksoy, S. Hepaksoy and J.M. Leitao,C.V. Mitchell and S. Kresovich (1999) Genetic redundancy and diversity among 'orange' accessionsin the US national sorghum collection assessed withsimple sequence repeat (SSR) markers. Crop Science, 39: 1215-1221.

[6] Simioniuc, D., R. Uptmoor, W. Friedt and F. Ordon (2002) Genetic diversity and relationships among peacultivars (Pisum sativum L.) revealed by RAPDs andAFLPs. Plant Breeding, 121: 429-435.

[7] Aksoy U, Can HZ, Misirli A, Kara S, Seferoglu G, Sahin N (2003) Fig (Ficus carica L.) selection study for fresh market in Western Turkey. ActaHort 605: 197-203.

[8] Stover E, Aradhya M (2008) Fig genetic resources and research at the US National Clonal Germplasm Repository in Davis, California.ActaHort 798: 57-68.

[9] Giraldo E, Lopez Corrales M, Hormaza JI (2010) Selection of the most discriminating morphological qualitative variables for characterization of fig germplasm. J AmerSocHort Science 135: 240-249.

[10] Podgornik M, Vuk I, Vrhovnik I, Mavsar DB (2010) A survey and morphological evaluation of fi g (Ficus carica L.) genetic resources from Slovenia. SciHort 125: 380-389.

[11] Şimşek M, Yildirim H (2010) Fruit characteristics of the selected fi g genotypes.Afr J Biotechnol 9: 6056-6060.

[12] Dalkılıç Z, Mesav HO, Günver-Dalkılıç G, Kocataş H (2011) Genetic diversity of male fig (Ficus carica caprificus L.) genotypes with random amplified polymorphic DNA (RAPD) markers. Afr J Biotechnol 10:519-526. 
[13] Ben Salah M, Lejri MH (1995). Description phénopomologique de quatre variétés de figuier (Ficus carica L.) dans l'oasis de Gafsa. Rev. Régions Arides, 8(1/95): 3-15.

[14] Mars M, Chebli T, Marrakchi M (1998) Multivariate analysis of fig (Ficus carica L.) germplasm in southern Tunisia. Acta Hort., 480: 75-81.

[15] Chatti K, Hannachi-Salhi A, Mars M, Marrakchi M, Trifi M (2004). Analyse de la diversité génétique de cultivars tunisiens de figuier (Ficus carica L.) à l'aide de caractères morphologiques. Fruits, 59: 49-61.

[16] Mars M, Gaaliche B, Ouerfelli I, Chouat S (2009). Systèmes de Production et Ressources Génétiques du figuier (Ficus carica L.) à Djebba et Kesra, deux villages de montagne au nord ouest de la Tunisie. Rev. Régions Arides, 22: 33-45. 